Available online at GSC Online Press Directory

GSC Biological and Pharmaceutical Sciences

e-ISSN: 2581-3250, CODEN (USA): GBPSC2

Journal homepage: https://www.gsconlinepress.com/journals/gscbps

(RESEARCH ARTICLE)

\title{
Distribution of Helminth parasites and seasonal rate of infection in Clarias batrachus (Jerdon, 1849) fishes of Savitri River from Konkan region, Maharashtra, India
}

\author{
Dandawate R.R.
}

\author{
Department of Zoology, Arts, Commerce and Science College, Sonai, Dist. Ahmednagar, Maharashtra,India
}

Publication history. Received on 10 April 2020; revised on 15 April 2020; accepted on 16 April 2020

Article DOI: https://doi.org/10.30574/gscbps.2020.11.1.0097

\begin{abstract}
The present study was undertaken to determine the incidence of helminth parasites in fishes in Savitri, river in Konkan region of Maharashtra. Fish and their parasites were collected during different seasons from various sites like Chiplun, Sangameshwar, Dapoli, Khed, Mandangad etc. For three year period and processed. Fish species namely Clarias batrachus from these water bodies. The parasitological examination of fishes was carried as per methodology. The parasites were processed and identified with the help of key. The prevalence mean intensity and relative density of Helminth parasites were calculated in accordance. The study of Cestode parasite population of river water fishes of different regions of Ratnagiri district has been unde rtaken to investigate the phonological and innate factors such as season, habit and habitat. The investigation of parasitogenesis can provide data for the prediction of integrated methods to achieve the regulation of number of parasites from various genera, quantitative data are vital.
\end{abstract}

Keywords. Cestode; Methodology; Platyhelminthes, carmine

\section{Introduction}

Konkan region is gifted with water resources of about 1000 ha. Comprising of lakes, streams, rivers, spring and sea, so suitable for fish culture. Aquaculture is one of most economically important strategies all over the world and fishes are most beneficial and nutritional resources of human being. The aquatics environment of fresh water resources encompasses a wide variety of feature namely physiochemical, biological, and ecological virtually all of which influence the maintenance of homeostasis, growth and reproduction of fish. The environmental factors are never constant they fluctuate and keep stresses on organism. These environmental alterations influence organisms physiologically in various ways. They may be lethal, modifying the effect of some other factors, directive or controlling. Same biotic environment factors may produce different effect. Fishes are hosts of number of parasites. Helminthes are one of the major groups of fish parasites and cause several loss of fish production. Fishes are infected by three major groups of helminthes i.e. Platyhelminths, Nematoda and Acanthocephala. About 30,0000 to 35,000 species of helminthes are reported worldwide which cause heavy loss of fish industry. The work on the population dynamics were carried out by many workers on different hosts Dogiel et al (1958), (1964), Susheela (1987), Mittal (1980), Hopkins (1959), Anderson (1976), Pennyuick (1971). Gorder and kates (1950) have shown the effects of seasons on the geographical distribution of the cestode parasites. The other workers also studied the effect of climatic factors on the helminths, include Kennedy (1968-1969), Lawrence (1970), Crofton (1971), Patrick and Esch (1977) have elaborately studied the effect of seasonal variations on parasites of a fish, Gasterosteusacileatus. While studying the abundance of parasitogenosis, i.e. distribution of the cestode population and related to other parameters.

\footnotetext{
${ }^{*}$ Corresponding author: DandawateR.R.
} 


\section{Material and methodology}

Fish species of Clarias batrachus (Jerdon, 1849) were collected on monthly basis and carried to in laboratory in plastic bags. Every effort was made to keep them alive. After giving them serial number, morphmetric characters, including total length, weight, etc. were determined. The fishes were killed by severing the spinal cord behind the head and were subsequently dissected by making an insertion from the anus towards the head, once they have dissected the intestine were removed and placed in normal saline solution in Petridices for examination. Parasites were collected as soon as possible after the death of fish to prevent deterioration. The intestine were pull carefully using sharp tweezers to ensure that the cestodes were kept intact then they were transfer to saline for few minutes, then two sample bottles of a hot alcohol formaldehyde acetic acid solution was added to kill and fix the specimens. The specimens were then stored in $70 \%$ alcohol. The cestodes were stained with Grenacher's borax caramine stain and identified.

\subsection{Identification of parasites}

The data collected was statically analyzed using SPSS version 20 software. Data was exposed by mean +SD and significant correlation and chi square test.The present study includes application of statistical methods to understand and distribution of cestode parasites both at infra and supra population levels for each species of parasites in three annual cycles January2002-December 2004.A careful elucidation was given from the observed data of changes in incidence, intensity density and index if infection of the parasites. Population investigations can provide data for the prediction of integrated methods to achieve the regulation of numbers of harmful parasites according to Kennedy (1975, 1978).An Indispensable study was made by author on different cestode parasites from marine fishes of Ratnagiri district and are namely Clarias batrachus (Jerdon, 1849), Mastacembellus armatus (Lacepede, 1800), Trygon sephen (Cuvier, 1871), Carcharias acutus (Muller and Henle, 1906), and Trygon zugei (Muller and Henle, 1841).

Index of infection of host by parasite is calculated by formula

Index of Infection $=$ No. of infected host X no of parasites collected $/$ Total no. of Host Examined

\section{Results and discussion}

It revealed that the cestode population was potentially dynamic with more or less durability, regularity and cyclic periodicity in the hosts under investigation. Each annual cycle comprises of rainy Season (June to September), winter Season (October to January), summer Season (February to May). On the basis of incidence of the infection the influence of annual season on the population of cestode parasites of fishes was carried out. It was observed that the incidence of infection by helminth parasites increased with host age. The infection levels were low in young hosts and showed remarkable infection rise in adults. Reports on ecological studies on helminth parasites of alimentary tract of the fishes are available from various countries like U.S.S.R., Poland, Bulgaria, Romania, France, Australia and Hungary. Notable contributions were made by Elton, C. S. (1927), Ferguson (1943), Cole (1954), Less (1962), Thomas (1963), Dogioel et al (1969), Kennedy (1967), (1971) (1972), (1974), Kisielewska (1970), Odum (1971), Whitlock (1972), Boxshall (1974), Esch (1977), Raghvender Rao (1978), and Rajeshrao Rao (1981) etc.Bykhovski (1929) studied the importance of influence of infection in annual seasons about trematodes in the Volga district U.S.S.R. An attempt was made on the suggestions of Dr. B. V. Jadhav to study the population dynamic of cestode parasites. Only statistical study of cestode parasite infection was made by the author. The data are shown in the tables further with month and year wise with their different hosts during study period January 2002 - December 2004 .In this three year period total $\mathbf{2 5 9}$ host (fishes) were examined, out of these fishes near about 144 fishes were infected. All infected fishes were when examined then it is observed that about 258 cestodes (Helmintjh parasites were collected. The percentage of infection of fishes from their parasites was 56\%..These parasites not only cause ill effect on fishes but also in higher infestation death of fishes also observed .These parasites causes disturbances in metabolic activates of fishes Parasites themselves ingress immunity power in their self body for resistance against fish immunity. 
Table 1 Population of Cestode Parasites From Clarias batrachus (Jerdon, 1849) During the Year Jan.2002 to Dec.2004.

\begin{tabular}{|c|c|c|c|c|c|c|c|c|}
\hline $\begin{array}{l}\text { Sr. } \\
\text { No }\end{array}$ & $\begin{array}{l}\text { Month \& } \\
\text { Year }\end{array}$ & $\begin{array}{l}\text { dissect } \\
\text { ed } \\
\text { hosts }\end{array}$ & $\begin{array}{l}\text { infected } \\
\text { hosts }\end{array}$ & $\begin{array}{l}\text { cestode } \\
\text { parasites }\end{array}$ & Parasite Genera & Locality & $\begin{array}{l}\text { Index of } \\
\text { Infection }\end{array}$ & $\begin{array}{l}\text { Incidence } \\
\%\end{array}$ \\
\hline 1 & Jan. 02 & 08 & 04 & 12 & Circumoncobothrium & Chiplun & 06 & $50 \%$ \\
\hline 2 & Feb.02 & 07 & 05 & 17 & Circumoncobothrium & Sangameshwar & 12.12 & $77 \%$ \\
\hline 3 & Mar.02 & 09 & 07 & 20 & Circumoncobothrium & Dapoli & 15.55 & $71 \%$ \\
\hline 4 & Apr.02 & 08 & 05 & 09 & Circumoncobothrium & Khed & 5.6 & $62 \%$ \\
\hline 5 & May.02 & 10 & 07 & 05 & Circumoncobothrium & Mandangad & 3.5 & $70 \%$ \\
\hline 6 & June.02 & 00 & 00 & 00 & 00 & ---- & 00 & $0 \%$ \\
\hline 7 & July.02 & 00 & 00 & 00 & 00 & ---- & 00 & $0 \%$ \\
\hline 8 & Aug. 02 & 00 & 00 & 00 & 00 & ---- & 00 & $0 \%$ \\
\hline 9 & Sept. 02 & 09 & 03 & 07 & Circumoncobothrium & Khed & 2.33 & $33 \%$ \\
\hline 10 & Oct.02 & 10 & 05 & 07 & Circumoncobothrium & Chiplun & 3.5 & $50 \%$ \\
\hline 11 & Nov.02 & 10 & 05 & 10 & Circumoncobothrium & Sangameshwar & 05 & $50 \%$ \\
\hline 12 & Dec.02 & 17 & 08 & 11 & Circumoncobothrium & Khed & 5.17 & $47 \%$ \\
\hline 13 & Jan. 03 & 10 & 05 & 14 & Circumoncobothrium & Chiplun & 07 & $50 \%$ \\
\hline 14 & Feb.03 & 10 & 08 & 19 & Circumoncobothrium & Khed & 15.2 & $80 \%$ \\
\hline 15 & Mar.03 & 12 & 10 & 22 & Circumoncobothrium & Mandangadh & 18.33 & $83 \%$ \\
\hline 16 & Apr.03 & 13 & 09 & 15 & Circumoncobothrium & Dapoli & 10.38 & $70 \%$ \\
\hline 17 & May.03 & 07 & 04 & 10 & Circumoncobothrium & Sangameshwar & 5.71 & $58 \%$ \\
\hline 18 & June.03 & 00 & 00 & 00 & 00 & ---- & 00 & $0 \%$ \\
\hline 19 & July.03 & 00 & 00 & 00 & 00 & ---- & 00 & $0 \%$ \\
\hline 20 & Aug. 03 & 00 & 00 & 00 & 00 & ---- & 00 & $0 \%$ \\
\hline 21 & Sept. 03 & 07 & 02 & 05 & Circumoncobothrium & Dapoli & 1.42 & $29 \%$ \\
\hline 22 & Oct.03 & 10 & 03 & 07 & Circumoncobothrium & Khed & 2.1 & $33 \%$ \\
\hline 23 & Nov.03 & 12 & 04 & 10 & Circumoncobothrium & Sangameshwar & 3.33 & $34 \%$ \\
\hline 24 & Dec.03 & 07 & 05 & 12 & Circumoncobothrium & Ciplun & 10 & $71 \%$ \\
\hline 25 & Jan. 04 & 12 & 05 & 08 & Circumoncobothrium & Chiplun & 3.33 & $41 \%$ \\
\hline 26 & Feb.04 & 08 & 06 & 10 & Circumoncobothrium & Sangameshwar & 7.5 & $75 \%$ \\
\hline 27 & Mar.04 & 11 & 10 & 19 & Circumoncobothrium & Dapoli & 17.27 & $91 \%$ \\
\hline 28 & Apr.04 & 06 & 04 & 09 & Circumoncobothrium & Khed & 06 & $66 \%$ \\
\hline 29 & May.04 & 05 & 03 & 07 & Circumoncobothrium & Chiplun & 07 & $60 \%$ \\
\hline 30 & June.04 & 00 & 00 & 00 & 00 & ---- & 00 & $0 \%$ \\
\hline 31 & July.04 & 00 & 00 & 00 & 00 & ---- & 00 & $0 \%$ \\
\hline 32 & Aug. 04 & 00 & 00 & 00 & 00 & ---- & 00 & $0 \%$ \\
\hline 33 & Sept. 04 & 06 & 02 & 03 & Circumoncobothrium & Khed & 01 & $33 \%$ \\
\hline 34 & Oct.04 & 10 & 03 & 04 & Circumoncobothrium & Khed & 1.2 & $30 \%$ \\
\hline 35 & Nov.04 & 12 & 08 & 05 & Circumoncobothrium & Mandangadh & 3.33 & $67 \%$ \\
\hline \multirow[t]{2}{*}{36} & Dec.04 & 13 & 04 & 08 & Circumoncobothrium & Dapoli & 2.46 & $31 \%$ \\
\hline & Total & 259 & 144 & 285 & - & - & 158.456 & $56 \%$ \\
\hline
\end{tabular}



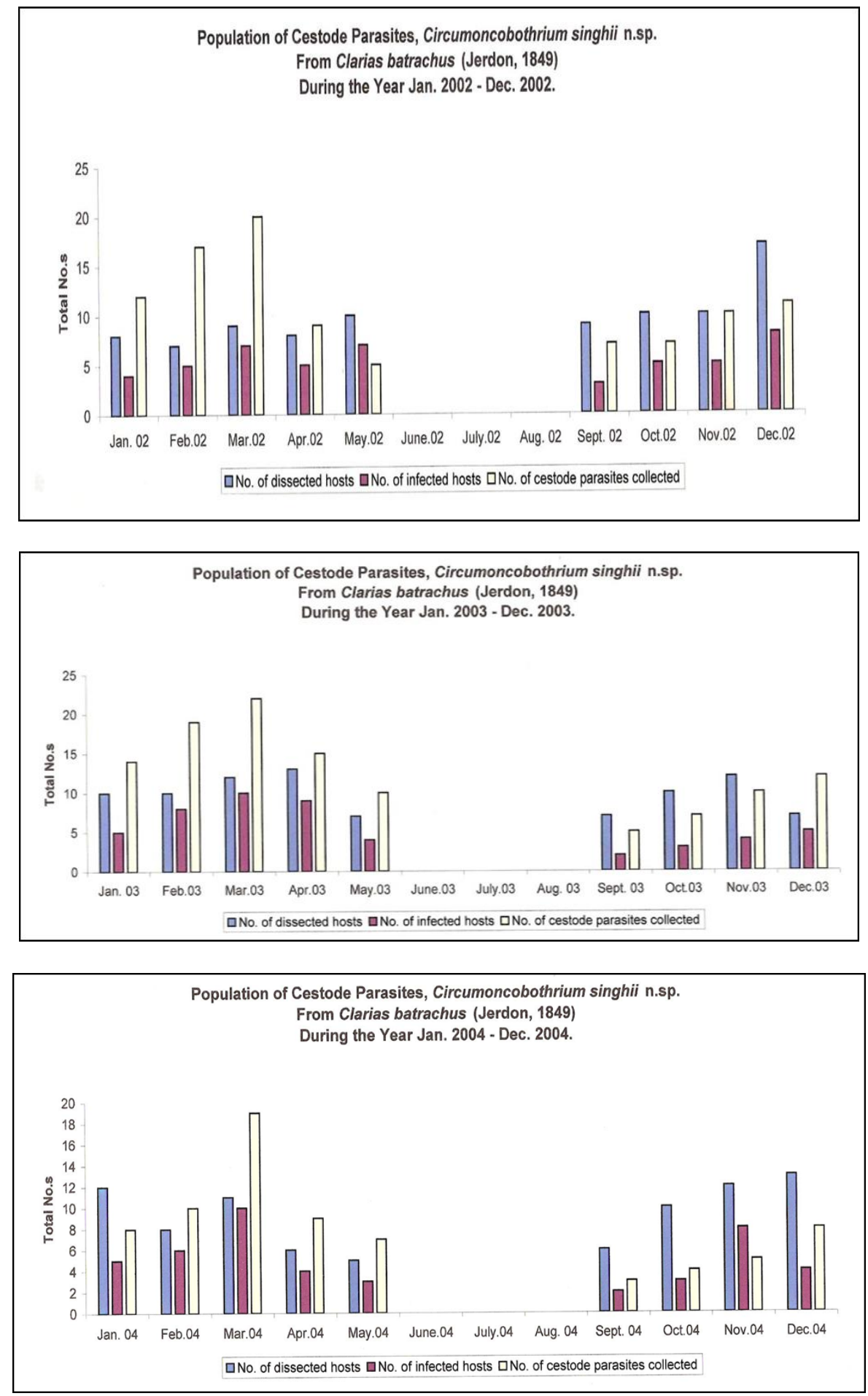

Figure 1 Graphical representation of Seasonal variation of Cestode parasites

\section{Conclusion}

Since much of work is not undertaken to study the nature of helminths population in certain fresh water fishes of various places of Ratnagiri district, (M. S.) India All parasites show higher prevalence during winter. Parasitic infections were prevalent more in male fishes compared to female. The presence of the parasites had reduced the condition coefficient of the infected fishes in all water bodies. Infection pattern of Circumoncobothrium were greatly influenced by season, fish species and type of water body. It was seen that overall prevalence of Circumoncobothrium was low at Khed Lake and river savitri with maximum infection level during summer months and least during winter months, also rivers is highly polluted at sangameshwar and Dapoli during summer. Hence cestodes showed seasonal alterations associated 
with environmental changes. The abrupt increase in cestode duration of life of the infective larva and has been reported to assist in the transfer of health infection like Circumoncobothrium It is also observe that male host (Clariasbatrachus fish) had significantly higher parasite intensity than female.

\section{Compliance with ethical standards}

\section{Acknowledgments}

The Author thanks to Principal, Arts, Commerce and Science College Sonai for providing Laboratory facilities

\section{Disclosure of conflict of interest}

This article deals with effect and seasonal distribution of endoparasites (Cestode) on their host (Fishes).It also brings awareness among people regarding parasitic infection on health.

\section{References}

[1] Anderson RM. (1976). Seasonal variation in the population dynamic of caryophhyll aceouslatticesparasitol, (72),281-395.

[2] Baylis HA. (1910). some parasites from lake Tanganyika ann,Mag Hist.10

[3] Bhure, Nanware. (2016). Prevalence and diversity of cestodeparasite, freshwater fishes of genus Channascopoli, $177(33), 15-26$.

[4] Bhat FA and Yousu ARf. (2004). "Limnological features of lotic system of Kashmir"inBioresouces concerns and Conservation N.K.Azra\& A.R. yourself, 56-70.

[5] Bagge AM and Valtonen ET. (1996). Experimental study on the influence of paper and pulp milleffuent on parasite communities of roach (Rutilusrutilus) Para, 5, 499-508.

[6] DholeJayant. (2009). Population dynamic of cestode parasites in Mastacembalus armatus from Omarabad District. Ecotech, 1(2), 156-157.

[7] Dobson VA. (1985). The population dynamic of competition between parasites,parasitol, 1(2), 317-347.

[8] JhaAN andMistra TN. (1992). Seasonal occurrence ofhelminth parasites in fishes of Sikandarpurreservoir Muzaffarpur. Indian J. of Helminthlogy, 44(1), 1-8.

[9] Pennyuick KL. (1971). Seasonal Variations in the parasitic population of three spineds ticklebacks, Gasterost eusaculeatus L.Parasitology, 63, 373-388.

[10] Perrenoud W. (1931). Research anatomiquesat histologique surquelques cestodes de Scalaciens. Rev.SuisseZool, $38,469-555$.

[11] Petersson. (1971). The effect of lake regulation on population of cestode parasites of white fish C. Olkos, 22(1), 74-83.

[12] Shomorendra M andJhaan KP. (2005). Seasonal occurrence of helminth parasites in fishes of Lohtaklake , Manipur UP J.of Zoology,25(1),23-27.

[13] Vincent AG and font WF. (2003). "Seasonal and yearly population dynamics of two exotic helminthes ,Camallanuscotti\& B. acehelognathi parasitizing exotic fishes in Waianu Stream,0 ahu ,Hawaii” The J.parasitology, 89(4),756-760.

[14] Zarga UR. (2010). Impact of eutrophication on health of fishes in Kashmir lakes,Uniof Srinagar.

\section{How to cite this article}

R.R.Dandawate. (2020). Distribution of helminth parasites and seasonal rate of infection in Clarias batrachus (jerdon, 1849) fishes of Savitri river from Konkan region, Maharashtra.GSC Biological and Pharmaceutical Sciences, 11(1), 127131. 